\title{
The United States: conditions for accelerating decarbonisation in a politically divided country
}

\author{
Guri Bang ${ }^{1,2}$
}

Accepted: 25 January 2021 / Published online: 17 February 2021

(c) The Author(s), under exclusive licence to Springer Nature B.V. part of Springer Nature 2021

\begin{abstract}
President Biden faces tremendous challenges to overcome political polarisation as he re-commits the United States to the Paris Agreement on Climate Change and promises decarbonisation of the US economy over the next three decades. To achieve deep decarbonisation, recent scholarship identifies the crucial role of broad policy mixes that create reinforcing effects between climate and energy policies to trigger technological innovation, restrict polluting activities, promote green growth, and ensure just energy transitions. Drawing on this literature, the article explores the conditions for developing such policy mixes in the US context in three policy phases. How and why have key policy conditions developed differently in the climate- and energy policy fields, and to what effect for decarbonisation policies? The analysis shows that growing political polarisation blocked bipartisan agreement, produced negative policy feedback, and caused instability in the climate policy field, whereas these mechanisms did not dominate the energy policy field. A more bipartisan approach to renewable energy policy allowed long-term experience and positive feedback in energy-policy programmes that helped to trigger technology innovation and subsequent GHG emissions cuts. Different policy conditions within these policy fields discouraged a coupling between them that could have facilitated green-growth policies. The economic shock caused by the coronavirus pandemic may potentially change policy conditions and build a path to deep US decarbonisation in the future, but only if political polarisation on climate change can be overcome.
\end{abstract}

Keywords United States $\cdot$ Climate policy $\cdot$ Energy policy $\cdot$ Green growth $\cdot$ Political polarisation

$\begin{array}{ll}\text { Abbreviations } \\ \text { BTU } & \text { British Thermal Unit } \\ \text { DOE } & \text { Department of Energy } \\ \text { ENGO } & \text { Environmental Non-Governmental Organisation } \\ \text { EPA } & \text { Environmental Protection Agency } \\ \text { GHG } & \text { Greenhouse Gas }\end{array}$

Guri Bang

guri.bang@nupi.no

1 Norwegian Institute of International Affairs, P.O.Box 7024, 0130 OSLO, Norway

2 CICERO - Center for International Climate Research, OSLO, Norway 


$\begin{array}{ll}\text { GND } & \text { Green New Deal } \\ \text { NASA } & \text { National Aeronautics and Space Administration } \\ \text { NOAA } & \text { National Oceanic and Atmospheric Administration } \\ \text { PA } & \text { Paris Agreement } \\ \text { PV } & \text { Photovoltaic } \\ \text { R\&D } & \text { Research and Development } \\ \text { US } & \text { United States }\end{array}$

\section{Introduction}

President Biden is re-committing the United States to the 2015 Paris Agreement (PA) and promises to transform US climate and energy policy to enable decarbonisation of the economy by 2050 . To accomplish this draconian task, Biden must accelerate the green transition and overcome substantial political barriers. The United States is one of few major emitters to cut GHG emissions substantially in recent years, since 2007 breaking its decades-long upward emissions trend that had been tightly coupled to economic growth, energy use, and population increase. Policy-induced technology change in the energy sector sparking a shale-gas boom and rapid renewable energy growth has been crucial for US emissions cuts (EIA 2018, 2020a). The climate policy field, by contrast, is characterised by low policy durability (Skodvin and Bang 2019). Examples include the broken promises related to US participation in international climate cooperation (as with the Kyoto and Paris agreements) and attempts at strengthening national climate policy under President Obama, with subsequent policy rollbacks by President Trump.

A growing literature emphasise that deep decarbonisation require broad policy mixes that can generate reinforcing effects between climate and energy policies, and trigger technological innovation, restrict polluting activities, promote green growth, and ensure just energy transitions (Kivimaa and Kern 2016; Rogge and Reichardt 2016; Kern et al. 2019). Drawing on this literature, the article explores the conditions for developing such policy mixes in the US context. How and why have key policy conditions developed differently in the climate- and energy policy fields, and to what effect for decarbonisation policies? The analysis proceeds in six steps. In Sect. 2, following the policy mix literature, four policy conditions for decarbonisation and green growth are identified. Section 3 assesses why, in the period 1990-2015, US climate policy played a minor role in comparison with energy $R \& D$ policy (in combination with market drivers) for the technology change that fuelled the rise of renewables and shale gas. The focus is on the US-specific institutional, political, and structural factors that facilitated energy-policy change while hampering climate-policy change. Section 4 explores how policy conditions for decarbonisation deteriorated under the Trump administration. Specifically, the dynamics of US federalism are explored by examining efforts by climate activist states like California and New York to take independent action aimed at overcoming the federal government's inaction. In Sect. 5, challenges for the next decade are assessed, as the US re-joins the PA in 2021. Potentially, the Covid19 pandemic could influence the willingness of the federal government to apply political levers, including funding, to boost the economy and create new jobs, while taking greengrowth perspectives into account. Section 6 provides concluding remarks. 


\section{Conceptual framework: policy mixes and green growth}

To achieve deep, economy-wide decarbonisation that can contribute to fulfilling the PA temperature targets, an encompassing energy transition is needed (Victor et al. 2019). Technology innovation and substitution are crucial for the energy transition, and institutional, political, and structural changes incentivising technological progress can help enable green growth - a decoupling of economic growth from environmental impacts (see e.g. Antal and Van den Bergh 2016; Hickel and Kallis 2019). Increasingly, scholars emphasise that single instruments like carbon pricing are insufficient to accomplish decarbonisation: broader policy mixes with reinforcing effects are required to accelerate the transition (Kivimaa and Kern 2016; Rogge and Reichardt 2016; Kern et al. 2019).

Four policy conditions have been identified in the policy mix literature as important for enabling decarbonisation. First, green-growth policies should establish powerful pushincentives for targeted research and innovation, including support for pilot and demonstration projects, to spearhead the development of new, fossil-free technological solutions and reduce the costs of low-carbon technologies (Geels 2014; Victor et al. 2019). Simultaneously, market incentives (pull-incentives) must be provided that lower the risk for investments, to promote rapid deployment and market uptake of low-carbon technologies (Åhman et al. 2018).

Second, targeted policy packages can drive green growth when they promote new business opportunities while constraining support for polluting activities. Such incentives can help to create 'green' jobs, establish new niches, and hence reduce emissions. Studies have examined how new combinations of policy instruments may initiate the transition by redirecting and accelerating technological change (Jordan and Huitema 2014; Hawlett and del Rio 2015; Kivimaa and Kern 2016; Rogge and Reichardt 2016). Policy packages are needed to support innovations that decarbonise energy systems, but also for more comprehensive sustainability transitions (Kern et al. 2019). A broad policy mix for green growth should include instruments aimed at promoting new 'green' business opportunities and constraining the support for existing polluting industries (Kivimaa and Kern 2016).

Increasingly, a new dimension related to the social acceptability-and the political feasibility — of climate policy packages has gained scholarly attention: serious consideration of environmental justice and just energy transition concerns. Policies should incentivise green growth across the entire population, also vulnerable, low-income groups, while cushioning the consequences for those negatively affected by the transition. Recent studies emphasise that social acceptance of climate-policy change requires inclusive processes in which affected groups have a genuine stake in the design and implementation of decarbonisation policies (Bächtiger et al. 2018; Healy and Barry 2017; Ostrom 1990); and redistributive measures whereby governments couple decarbonisation policies with offsetting benefits-including benefits related to the socio-economic opportunities created by decarbonisation-for groups vulnerable to its adverse effects (Green and Gambhir 2019; Trebilcock 2014; Vogt et al. 2017).

Third, scholars have found that effective policy packages establish self-enforcing policy feedback, drawing on lessons from successful domestic implementation experiences. Ideally, policymakers learn from previous policy programmes that proved effective, adding implementation features that help reinforce policies to strengthen their effects (Jordan and Matt 2014; Edmondson et al. 2019). However, policy feedback may stem from both positive and negative implementation experiences. While green-growth policies can entail various benefits-like energy security, 'green' jobs, green technology innovation and 
alleviation of related problems like air pollution-adverse effects like political, administrative, and economic costs may spur negative policy feedback that undermines reformed policies and reduces the likelihood for deep decarbonisation (Skjærseth 2018).

Finally, green-growth policy packages must recognise that established institutions and policies are inherently hard to change because structural forces such as path dependency and its self-reinforcing mechanisms cause stability (Powell and DiMaggio 1991; Skocpol and Pierson 2002; Pierson 2000). An exogenous shock like a major economic recession can be a powerful disrupter, enabling openness for rapid policy innovation and important changes in status-quo policies (Kingdon 2003; Capoccia 2015). However, the direction of change-reinforcing the status quo, accelerating policy change, or causing lower ambitions-is context-dependent. The coronavirus pandemic and the ensuing economic downturn is one such external shock that may jolt policy change relevant for US decarbonisation.

Employing case study analysis, this article explores the development of US climate and energy policy over time: before the Paris Agreement, after Paris, and projections for the next decade. The aim is to assess how and why the four policy conditions described above have developed differently within the climate- and energy policy fields. The analysis builds on a systematic literature and evidence review based on data from primary and secondary sources. The data material includes $15 \mathrm{semi}$-structured interviews with representatives from the US Congress, federal agencies, energy industry associations, think-tanks, academics, and ENGOs ${ }^{1}$; as well as archival and other written data collected during fieldtrips to Washington DC in 2016 and 2018 such as policy position papers, congressional records, government and congressional reports, academic literature, consultancy reports, blogs and newspaper articles. Additional data material has been added from online sources to reflect recent events, including consequences of the pandemic and the 2020 elections.

\section{Before Paris: energy technology change and climate policy instability (1990-2015)}

US GHG emissions peaked in 2007, subsequently decreasing to 1990 levels by 2017 (EPA 2020). Despite continuous economic and population growth, technology change induced GHG emissions cuts through improvements in energy efficiency, reductions in the carbon intensity of economic growth, and changes in the mix of energy sources used in electricity production (EIA 2018). The following sections explore push/pull-policy condition differences in the energy policy and climate policy fields in this phase.

\subsection{Energy policy}

Policy conditions in the energy policy field facilitated beneficial push and pull incentive structures for low-carbon energy policies and instruments in this policy phase (see Table 1). Importantly, the federal government developed strong and coordinated structures for public support of low-carbon technology innovation since the 1970s. Coordinated efforts across federal government agencies, national laboratories, and universities have resulted in major

\footnotetext{
1 Interviews were conducted in November 2016 and November 2018 in Washington DC. Interviewees were granted anonymity, and their assessments are mainly employed as background information for interpreting written sources. See " Appendix A" for a list of interviewees.
} 
scientific innovations, addressing large-scale, complex R\&D challenges with an emphasis on translating basic science to innovation (DOE 2020).

The coordinated federal structures for push-policies have resulted in technology innovation spurring GHG emissions cuts. For instance, since the 1980s the Department of Energy and national laboratories supported technology innovation research and development (R\&D) trying to combine hydraulic fracturing with horizontal drilling (Wang and Krupnick 2013). The commercial breakthrough for fracking came in 2002, when a new combination of chemicals made the injection fluid more viscous, increasing its fracking potential (Wang and Krupnick 2013). The technology has since spread throughout the US oil and gas industry. As a result, after decades of dominance in the energy mix, coal experienced a decline in demand in the utility sector after 2007, while natural gas gained stronger market positions (EIA 2018; EIA 2020b).

Moreover, federal push-policies helped pioneer renewable energy technology in the 1980s and 1990s, including PV panels at the solar thermal plant Solar One in California (NREL 2001). Similarly, wind turbine technology was developed in California in the 1970s and 1980s and deployed successfully in Texas in the 1990s and 2000s, showcasing the feasibility of fossil-free energy production (WETO 2021). Hence, the Department of Energy (DOE) was the main funder of solar and wind energy innovation in the pioneering stages and in general an important provider of financial support for cuttingedge renewable energy R\&D, via loans and direct subsidies, aiding early-stage technology to become fully developed and deployed, with the aim of fuelling innovation-based economic growth (DOE 2020). Since 1977, some 17\% of DOE energy technology funding has been directed to renewable energy technology (Clark 2018).

While push-policies like technological innovation and commercialisation were important drivers behind cuts in GHG emissions in the United States since 2007, the role of pull-policy and governance was central in underpinning this development (see Table 1 for an overview of key pull policies). Government subsidies and targeted policy incentives facilitated technology change in the energy sector, not least the policy incentives adopted in the 2005 Energy Policy Act that was passed with large bipartisan support (US Senate 2005). The 2005 Energy Policy Act established sweeping federal energy-policy reforms encompassing coal, nuclear, hydroelectric, ethanol, and oil and gas (GPO 2005). It provided controversial regulatory relief for the oil and gas fracking industry, with exemptions from some sections of the Safe Drinking Water Act of 1974 and the Clean Water Act of 1972. Moreover, the licensing process was changed, allowing more categorical exemptions from environmental assessments for new drilling projects, speeding up the process while reducing federal oversight of drilling and fracking operations (GPO 2005). These 2005 Energy Policy Act changes, continued under the 2007 Energy Policy Act, made operating costs lower for the industry and the economic return on investments in fracking technology very rewarding, helping to pave the way for explosive growth in shale gas drilling (Schreurs et al. 2009). Because of the subsequent price-fall for natural gas, market forces pushed coal out of the utility sector causing carbon emissions to fall.

Moreover, the development of renewable-energy technologies, particularly solar and wind energy technologies, was aided by federal supply-push policy incentives aimed at deploying renewable technologies. These policies were adopted in the Energy Policy Act of 2005 and in the American Recovery and Reinvestment Act of 2009 (Galli and Fisher 2016). The former authorised larger loan guarantees for the development and deployment of renewable-energy technologies. The American Recovery and Reinvestment Act of 2009 also provided loan guarantees for renewable-energy innovation, and direct funding 
for renewable-energy projects (Galli and Fisher 2016). Furthermore, federal tax incentives have been important policy drivers for the growth of wind, solar, and other renewables over the past two decades. These include investment and production tax credits for commercial and residential projects, and production tax credits that have been renewed by Congress regularly since first adopted in 1992, although such renewals have been vulnerable to disagreements and debate among legislators (CRS 2020). More than 30 states have implemented renewable portfolio standards that set a minimum amount of renewable-energy sources electricity producers can use for power production. A few states have a feed-intariff, which compensates customers who own renewable electricity production technology such as roof-top solar photovoltaic systems (DOE 2020).

In summary, renewable-energy policy incentives flourished at the state and federal levels thanks to relatively high degrees of bipartisan agreement in this policy field (Bang 2010; Kemp 2015). The above review of policies and instruments (summarised in Table 1) shows that concerns for energy security and energy independence drove a bipartisan strategy of supporting growth in all types of energy, including renewable, fossil, and nuclear, and such political steering helped to raise the long-term competitiveness of renewable energy technologies. Similarly, bipartisan federal legislation enabling subsidies and targeted incentives directed at technology innovation in the oil and gas industry facilitated the fracking boom that enabled a rapid decline of coal power plants (US Senate 2005).

\subsection{Climate policy}

Unlike the field of energy policy, where targeted subsidies and policy incentives to boost renewable energy technology change were made possible through bipartisan agreement at the federal level, attempts at climate policy change to cut GHG emissions encountered Congressional gridlock and disagreement (Bang and Schreurs 2017). The separation of powers among political institutions in the United States creates many veto-points in the policymaking process, as legislative proposals must first achieve majority support in both chambers of Congress to be adopted, and subsequently be signed by the president to be enacted. The many institutional veto-points create status- quo stability in the political system, unless broad bipartisan compromise on policy reform can be reached (Tsebelis 2002).

A review of policies in the field of climate policy reveals that bipartisanship has been lacking since the issue first reached the political agenda in the early 1990s (see Table 2 for a summary of climate policy reform efforts since 1990). President Clinton's efforts in 1993 to introduce a general tax on all energy forms (a Btu tax), as part of a broader deficit-reduction plan and also to promote energy conservation, encountered strong opposition from legislators in Congress and various industry stakeholders, and failed to gain majority support (Bang 2010). Clinton's attempts at climate policy leadership, peaking with the signing of the 1997 Kyoto Protocol, were reversed when George W. Bush took office in 2001 and immediately withdrew further US participation in the agreement (Hovi et al. 2012). The Bush Administration took steps to introduce alternative, less ambitious forms of international climate-policy cooperation through voluntary agreements like the International Partnership for the Hydrogen Economy, the Methane to Markets Partnership, and the Asia-Pacific Partnership on Clean Development and Climate. Moreover, Bush's domestic climate policy programme was mostly directed at reducing emissions intensity and was heavily criticised by the opposition as being too weak (Harris 2009). This led Democratgoverned states like California and New York to adopt state-level climate policies such as cap-and-trade to counteract federal inaction (Rabe 2016). 
Federal climate-policy bills attempting to introduce comprehensive measures like an economy-wide cap-and-trade system were debated in the US Congress in 2003, 2005, 2007, 2009, and 2010, but failed to gain majority support in both chambers (Bang and Schreurs 2017). Instead, in step with heightened political attention to climate change, the United States experienced increasing political polarisation on the issue (McCright and Dunlap 2011; Skocpol 2013). Since the 1990s, the Democrats in Congress have increasingly tended to vote in favour of climate-policy measures, while Republicans vote against (Dunlap et al. 2016). Surveys of citizens' attitudes towards climate change confirm such polarised views, with most Democrats being convinced that climate change is a humaninduced problem that needs greater political attention, while Republicans tend to take the opposite view (Dunlap et al. 2016). The contentious debate on the American Clean Energy and Security Act in 2009-2010 exemplified how polarisation hampers climate-policy change because bipartisan agreement becomes impossible. The bill was discussed at the same time as the 'Tea Party' movement mushroomed in the summer and autumn of 2009. This movement defined climate-change scepticism as a major issue and established itself as a political powerhouse within the Republican Party (Skocpol 2013).

Table 1 Overview of important low-carbon energy push and pull incentives

\begin{tabular}{ll}
\hline Policy conditions & Key low-carbon energy push and pull policies \\
\hline Supply-push incentives & Fracking technology innovation research (Department of Energy, \\
federal agencies, national laboratories, universities) \\
Renewable energy technology innovation research (Department of \\
Energy, federal agencies, national laboratories, universities) \\
Coordinated technology deployment support (Federal agencies) \\
2005 Energy Policy Act \\
2007 Energy Policy Act \\
2009 American Recovery and Reinvestment Act \\
Federal Renewable Electricity Production Credits and Investment \\
Tax Credits \\
State-level Renewable Portfolio Standards \\
State-level Feed-in Tariffs \\
\hline
\end{tabular}

Table 2 Overview of climate policy reform efforts 1993-2015

\begin{tabular}{ll}
\hline Policy conditions & Key climate policy reform proposals \\
\hline Demand-pull incentives & 1993 Btu tax (rejected) \\
& 1997 Kyoto Protocol (rejected) \\
& 2003 The International Partnership for the Hydrogen Economy (in effect) \\
& 2004 Methane to Markets Partnership (in effect) \\
& 2005 Asia-Pacific Partnership on Clean Development and Climate (elapsed) \\
State-level emissions reductions targets (growing number of states) & 2005 Regional Greenhouse Gas Initiative (in effect) \\
& 2006 California's cap-and-trade system (in effect) \\
& 2003 Climate Stewardship Act (rejected) \\
2005 Climate Stewardship and Innovation Act (rejected) & 2009 American Clean Energy and Security Act (passed House, not Senate) \\
2012 Obama's Climate Action Plan (several executive orders, later \\
rescinded) \\
2015 Clean Power Plan (rescinded) \\
\end{tabular}


After winning a second term in 2012 but facing a divided Congress with a Republican majority in the House, President Obama applied a different strategy for introducing climate policy. He now issued Executive Orders seeking to regulate GHG emissions, pushing a Climate Action Plan aimed at renewing and strengthening US climate policy and placing the United States as a leader in international climate cooperation (Bang and Schreurs 2017). Obama used Executive Orders to introduce regulations targeting emissions in the transport, utilities, and petroleum sectors, but these were later rescinded by President Trump and hence had little effect (Berardo and Holm 2018). For example, the Clean Power Plan introduced in 2015 aimed at reducing $\mathrm{CO}_{2}$ emissions from existing power plants by $32 \%$ below 2005 levels by 2030 but was rescinded shortly after Trump took office (Berardo and Holm 2018). Obama's extensive use of Executive Orders was perceived as controversial by Republican legislators because it circumvented Congress, hence nullifying the veto power of the minority that had stopped climate legislation in Obama's first term. Republicans attacked Obama's use of Executive Orders and polarisation around climate policy intensified in this period (Skodvin and Bang 2019).

The review above (see Table 2) shows that controversy and polarisation surrounding climate policy continued to deepen between 1990 and 2015, triggering veto-points in the US political system and blocking bipartisan agreement. Now characterised by instability, the federal climate-policy approach had essentially no impact for GHG emissions cuts. By contrast, in the field of energy policy, polarisation did not emerge-mainly because of bipartisan majority agreement on the need to develop all kinds of energy, for greater energy security and independence. The more bipartisan approach to energy policy allowed experience with renewable energy policies that in turn helped to trigger technology innovation and subsequent emissions cuts. The different policy conditions at work within these two policy fields ruled out any coupling between them that might have reinforced a greengrowth approach at the federal level. Instead, the climate policy field was characterised by negative policy feedback due to increasing levels of polarisation (Jordan and Matt 2014).

\section{After Paris (2016-2020): federal climate-policy rollbacks and state-level action}

The Paris Agreement was heralded as a game-changer for climate policy when it was adopted in December 2015, not least because the United States took a leadership role in the negotiations, together with China (Bang et al. 2016). Employing executive powers, President Obama signed and ratified the treaty before leaving office. Then, within a few months of being inaugurated as president in 2017, Donald Trump withdrew US participation in the Agreement, arguing that it would hurt the US economy. The instability and negative policy feedback characterising federal climate policy continued in the years after Paris.

\subsection{Climate policy rollback}

Several major policy changes relevant for GHG emissions levels were made when Donald Trump became president. Immediately after assuming power in 2017, the Trump Administration started a broad rollback effort targeting more than 100 environmental regulations and completed 83 of the regulatory rollbacks by the end of 2020 (see Sabin Center for Climate Change Law for a complete overview). In March 2017, President Trump issued an executive order directing the EPA to review all environmental regulations introduced 
by Obama and to "rescind or rewrite rules as needed to promote the President's goals of energy independence and economic growth" (The White House 2017: 1). Trump quickly issued specific executive orders to remove regulations targeting emissions in transportation, utilities, oil and gas production, and more-but the bureaucratic process involved to replace or rescind is complex and includes several steps that are time-consuming. For example, the process of removing the Clean Power Plan took more than 2 years and involved several public hearings, a commenting period, adjustment, and eventual finalisation of the new Affordable Clean Energy Rule in June 2019 (Skodvin and Bang 2019). As soon as the finalised rule was issued in June 2019, the EPA was challenged in court by opponents claiming the rule was too weak to serve the purpose of the Clean Air Act: to protect citizens from dangerous pollution and health risk (American Lung Association v. EPA, Docket No. 19-01,140 (D.C. Cir.)). Similar lengthy bureaucratic revision processes and subsequent legal challenges by opponents delayed several of the replacement regulations introduced by the Trump Administration (Sabin Center for Climate Change Law 2020).

The Trump rollback effort consolidated the trend in federal climate policy since the 1990s, where policy changes are removed before they can make an impact. The resultant policy instability makes concerted efforts to cut GHG emissions less effective than they could have been. Because of inefficient federal climate policy, the emissions reductions achieved since 2007 are mostly a result of technology-induced energy efficiency, less carbon-intensive GDP growth, and market-induced changes in the energy mix, as explained above. The problem for the future is that if deep polarisation over climate policy solutions continue, the United States is unlikely to strengthen climate policies sufficiently to trigger the encompassing decarbonisation of the economy necessary to avoid dangerous climate change (Victor et al. 2019).

\subsection{Renewable energy-policy durability}

Renewable energy policies, on the other hand, proved more durable and less riddled by polarisation even under the Trump Administration's populist approach to low-carbon policies. In every national budget proposal during his presidency, Trump suggested (but failed) to radically cut (up to 100\%) the climate-relevant funding for the DOE, the Department of the Interior, the EPA, NASA, NOAA, and the National Science Foundation (see e.g. Mooney 2019; Natter 2019). Collectively, these agencies form the backbone of federal efforts to support green-growth, low-carbon development of the economy and to advance the development of renewable energy technology. The Trump Administration specifically targeted the funding of the DOE Office of Energy Efficiency and Renewable Energy, which play a critical role in supporting clean energy by funding research that has sparked advances in wind, solar, and geothermal energy, as well as electric cars and LED lighting (Mooney 2019; Natter 2019). Moreover, Trump targeted the DOE Advanced Research Projects Agency-Energy (ARPA-E) which advances high-potential, high-impact energy technologies for generating, storing, and using energy that depend on government subsidies to become sufficiently mature to attract private-sector investment (DOE 2020). For both agency offices, the Trump Administration proposed $70-100 \%$ cuts in funding for each Fiscal Year Budget since 2017. However, the Congressional majority did not support such cuts in any national budget cycle, even despite Republican control over both chambers of Congress in 2017-2018 (Mooney 2019; Natter 2019). Indeed, a sizable bipartisan 
Congressional majority support the key energy-policy incentives that have undergirded technology-driven emissions cuts for decades, hence providing stability to enact energy policies that incentivise phasing in more renewables. These policies have provided positive feedback loops that help to establish renewables as a viable alternative to fossil fuels.

However, the Trump Administration gained majority support in Congress for providing more subsidies and targeted policy incentives to fossil-fuel production and consumption. The federal government provides significant policy support to oil, gas, and coal production, with this total growing as new subsidies are added and old ones are re-introduced, both at the state and federal levels (Whitley et al. 2018). Historically, the US government has encouraged domestic energy production by providing various tax subsidies to the fossil-fuel industry, including direct subsidies and tax benefits. Such subsidies increased under the Trump Administration (Laporte 2019). Although government subsidies to the fossil-fuel industry were originally introduced in times of high energy import dependence to lower the cost of domestic fossil-fuel production and develop new domestic energy sources, current continued use of fossil-fuel subsidies may hamper a low-carbon transition of the economy. As renewable energy technology is becoming cost-competitive with fossil electricity generation, and a green energy transition is emerging in many countries, the increased use of fossil-fuel subsidies could impede the US transition (Laporte 2019).

Despite repeated efforts by the Trump Administration to support the coal industry through direct subsidies and other policy incentives, coal continues to lose market shares. Notably, the switch to natural gas in US electricity production has accelerated apace with the fracking boom and availability of natural gas at lower prices than coal (EIA 2018). The fuel-switching trend in the utility sector is likely to continue for as long as natural gas is a cheaper, more competitive alternative to coal. Although this contributes to cuts in US GHG emissions, coal-to-gas fuel switching in electricity production will not in itself be enough to ramp up US emissions cuts to the level needed to achieve the PA goals of restricting global warming to less than $2{ }^{\circ} \mathrm{C}$. More ambitious climate action is needed, and some states, cities, and businesses have stepped up their efforts to counteract federal inaction.

\subsection{Federalism: subnational climate policy aiming to counteract federal inaction}

In the US political system, the states can function as laboratories for policy innovation: "It is one of the happiest incidents of the federal system that a single courageous state may, if its citizens choose, serve as a laboratory; and try novel social and economic experiments without risk to the rest of the country" (Brandeis 1932: 20). Hence, one advantage of US federalism is that new and experimental policies can be adopted to address states' needs, unsuccessful attempts can be abandoned, and learning from the successes of similar states can drive policy innovation and market chances (Rabe 2004; Shipan and Volden 2008; Volden 2006).

US states control their own energy- and climate policy to a large degree and may choose a different policy path than the federal government that help accelerate decarbonisation. For example, Texas introduced a Public Utility Regulatory Act in 1999 that, together with legislation that created Competitive Renewable Energy Zones for wind power transmission, enabled a steep rise in the state's wind energy over the following two decades (AWEA 2020). Even more significant, California has extensively exploited its discretion over climate- and energy policy by introducing a world-leading set of policies to curb GHG emissions (Bang, Victor and Andresen 2017). For instance, California adopted regulations for automobile emissions stricter than federal regulations in 2002 (CARB 2020). Thirteen 
states, together comprising around half of the US car market, chose to follow California, thereby putting strong pressure on the auto industry to adhere (CARB 2020). Moreover, California drew on decades of environmental regulatory expertise to develop a strong renewable portfolio standard and one of the world's most ambitious and well-functioning cap-and-trade systems (Bang, Victor and Andresen 2017).

California's leading role in pushing for green-growth policies took a new turn during Trump's presidency. California governors Brown and Newsom engaged in forming alliances among states, cities, and business networks seeking to defy the Trump Administration's regulatory rollbacks and pursue ambitious climate policies. Together with political leaders in New York and Washington state, Governor Brown initiated the declaration We Are Still In, which aimed to signal that many subnational actors intended to fulfil US pledges in the Paris Agreement even after Trump's decision to withdraw. Similarly, the US Climate Alliance aimed to intensify subnational action to drive down GHG emissions consistent with the goals of the PA. With these and other efforts, some of the most populous states and cities, together with large business actors, introduced ambitious climate policies to cut GHG emissions, despite inaction in the US Congress and Trump's regulation rollback efforts. At least 22 states and 500 cities introduced climate actions of some size, representing about $65 \%$ of the economy and population, and about $51 \%$ of GHG emissions (Hultman et al. 2019). Some 900 of the largest companies in the United States participate in climate-action alliances like America's Pledge to cut emissions (Hultman et al. 2019). The broad participation provides green market incentives for a growing share of the US economy, hence facilitating acceleration in green growth (Hultman et al. 2019).

A common feature in states with strong climate-action programmes is the dominance of Democrats in state government, notably in California, Washington, and New York. Moreover, progressive legislators in these states enjoy strong public support for climate action (Funk and Hefferon 2019). Republican governed states are not equally likely to participate in alliances like America's Pledge.

\section{The future (2020-2030)}

Without stronger federal climate policies-despite state, city, and business alliances efforts - the US is unlikely to accelerate emissions cuts at a scale necessary to reach PA goals (Victor et al. 2019). Decarbonisation requires an encompassing policy package that couples and reinforces energy- and climate policy incentives.

The Green New Deal (GND) resolution proposed by Democratic Congressional representatives Ocasio-Cortez and Markey in 2019 sketched the contours of a policy package for accelerating emissions cuts (Friedman 2019). The aim was to cut US emissions to net-zero by 2030 , with the federal government taking a leading role in creating green jobs, reducing air and water pollution, and ending social inequality and oppression. The plan called for decarbonisation of electricity production, an upgraded and digital power grid, energyefficient buildings, and electrification of transport. Further, GND envisioned environmental justice and green economic development through a just transition for regions and communities currently dependent on jobs in fossil-fuel industries (Friedman 2019).

While the GND resolution sparked intense polarisation between Democrats and Republicans in Congress, several GND goals were eventually included in President Biden's climate plan. His ambitious green growth-oriented policy package promises $\$ 2$ trillion for investment in transforming infrastructure, transport, energy technology, and buildings to 
cut emissions drastically in coming decades (Biden 2020). The aim is to build a net-zero emissions economy by 2050 , a carbon-free electricity sector by 2035 , to re-join the Paris Agreement and take a leadership role in international climate cooperation. Importantly, the Biden plan pays serious attention to environmental justice by reserving $40 \%$ of the $\$ 2$ trillion for vulnerable, low-income communities and for regions adversely affected by the transition, aiming to spark green economic growth and new green jobs in those communities (Biden 2020). Such linkages echo recent scholarship emphasising that social acceptance for climate-policy change hinges on inclusive processes and redistributive measures that dampen adverse effects of the policies (Green and Gambhir 2019).

However, ambitious climate legislation that could cement federal climate policy will be difficult to get adopted in the US Senate as long as majorities remain slim and polarisation persists. Democrats control slim majorities in the House and Senate in the 2021-22 period. Hence, the budget process, requiring simple majority (51\%), may be employed for some green policy measures but would require full support from all Democrats, which is not assured based on previous experience like the rejection of climate legislation in the Senate during the Obama administration when Democrats held 59 seats. It will no doubt be challenging to enact Biden's climate plan, including its \$2 trillion spending budget. Likely, Biden will have to employ Executive Orders to implement as much as he can of the climate plan, knowing that such measures do not provide the same degree of stability as legislation and may only last as long as his presidency.

The US economy took a hard hit from the coronavirus crisis in 2020. Pandemic lockdown measures brought unemployment for tens of millions of workers and substantial losses in economic output. The drag on the economy could last up to a decade, according to projections by the Congressional Budget Office: US economic output could be cut by as much as 3\% by 2030, a loss of $\$ 7.9$ trillion (CBO 2020). The US Congress adopted economic relief bills in March (\$2.2 trillion) and December 2020 (\$900 billion) to contain some of the worst effects of the pandemic, but with scant attention to notions like green growth or a 'green recovery' although the latter included some provisions for investment in renewable energy technology (in contrast to discussions about an encompassing green transition in the EU; see Skjærseth, this issue) (Newberger 2020). The coronavirus crisis contributed to push social injustice protests to centre-stage in US politics, exemplifying for many the need for green welfare reform as proposed in the Green New Deal and Biden's climate plan. With a slim majority in both chambers of Congress in 2021-22, President Biden will likely seek support for green economic stimulus packages that can help to jumpstart both the economy and a socially just energy transition.

\section{Concluding remarks}

This article has explored how and why policy conditions have developed differently in the climate- and energy policy fields, and to what effect for developing broad policy mixes for decarbonisation in the United States. The analysis shows that growing political polarisation hampered bipartisan agreement, prevented implementation of climate policy reforms, and produced negative policy feedback in the climate policy field. Such mechanisms were not similarly present in the energy policy field where a bipartisan approach to renewable energy incentives allowed long-term experience, policy learning, and positive feedback that helped to trigger technology innovation and subsequent emissions cuts. 
The main conclusion is that different policy conditions within the energy and climate policy fields have discouraged a coupling between them which is crucial for accelerating the decarbonisation of the economy. This lack of coupling may pose a big challenge for the Biden administration, whose promise to accelerate decarbonisation of the economy will require encompassing policy packages that facilitate massive technology innovation and deployment, accompanied by economic restructuring along the lines of green-growth theory-while also ensuring that the transition is just and fair. The United States has substantial potential for making such a transition, given its strong, coordinated federal technology innovation competence and regulatory expertise in energy R\&D support. But bipartisan agreement on climate change must first become a common goal for US lawmakers.

Future research could investigate other avenues to design broad policy mixes for US decarbonisation. With the Biden administration, we are likely to see an emerging understanding that climate change cannot be addressed in isolation: it is a challenge that requires an encompassing, government-wide response. A more holistic approach to decarbonisation could be a step towards more bipartisan support. That would also improve US credibility as a reliable long-term partner in the PA and other international climate cooperation, avoiding the current shifting state of US climate policies in step with changing political majorities on Capitol Hill.

\section{Appendix A: Interviews, Washington DC}

Researcher, Resources for the Future, Nov. 7, 2016.

Political advisor, Senate Foreign Relations Committee, Nov. 9, 2016.

Researcher, Resources for the Future, Nov. 9, 2016.

Environmental attaché, Norwegian Embassy, Nov. 9, 2016.

Energy policy advisor, PG\&E, Nov. 10, 2016.

Former Obama administration official, Center for American Progress, Nov. 10, 2016.

Climate policy expert, EDF, Nov. 10, 2016.

Researcher, Brookings Institution, Nov. 10, 2016.

Climate policy expert, NRDC, Nov. 10, 2016.

Professor, University of Maryland, Nov. 11, 2016.

Professor, University of Maryland, Nov. 12, 2016.

Three Trump administration climate- and energy policy officials, EPA, Nov. 5, 2018.

Three energy policy analysts, Heritage Foundation, Nov. 6, 2018.

Two former Obama administration EPA officials, Nov. 7, 2018.

Former Obama White House climate policy adviser, Nov. 8, 2018.

Acknowledgements The author wants to thank two reviewers, the special issue team, Joyeeta Gupta, Tora Skodvin, and Miranda Schreurs for very helpful comments and discussions.

\section{References}

Ahman, M., Skjærseth, J. B., \& Eikeland, P. O. (2018). Demonstrating climate mitigation technologies: An early assessment of the NER 300 programme. Energy Policy, 117, 100-107.

American Wind Energy Association (2020). Wind Energy in Texas. Fact sheet. https://www.awea.org/Awea/ media/Resources/StateFactSheets/Texas.pdf Retrieved from 14 December 2020. 
Antal, M., \& Van Den Bergh, J. (2016). Green growth and climate change: Conceptual and empirical considerations. Climate Policy, 16(2), 165-177.

Bächtiger, A., Dryzek, J., Mansbridge, J., \& Warren, M. (Eds.). (2018). Oxford handbook of deliberative democracy. Oxford: Oxford University Press.

Bang, G. (2010). Energy security and climate change concerns: Triggers for energy policy change in the United States? Energy Policy, 38(4), 1645-1653.

Bang, G., Hovi, J., \& Skodvin, T. (2016). The Paris Agreement: Short-term and long-term effectiveness. Politics and Governance, 4(3), 209-218.

Bang, G., \& Schreurs, M. A. (2017). The United States: The challenge of global climate leadership in a politically divided state. In R. Wurzel, J. Connelly, \& D. Liefferink (Eds.), The European Union in international climate change politics: Still taking a lead? London: Routledge.

Bang, G., Victor, D. G., \& Andresen, S. E. (2017). California's cap-and-trade system - diffusion and lessons. Global Environmental Politics, 17(3), 12-30.

Berardo, R., \& Holm, F. (2018). The participation of core stakeholders in the design of, and challenges to, the US clean power plan. Climate Policy. https://doi.org/10.1080/14693062.2018.1478792.

Biden, J. (2020). The Biden Plan to Build a Modern, Sustainable Infrastructure and an Equitable Clean Energy Future. Election Platform. https://joebiden.com/clean-energy/ Retrieved from 20 Oct 2020

Brandeis, L. (1932). U.S. Supreme Court: NEW STATE ICE CO. v. LIEBMANN. No. 463. Argued Feb. 19. https://www.scribd.com/document/310818487/New-State-Ice-Co-v-Liebmann-285-U-S-262-1932. Retrieved from 21 Oct 2020

California Air Resources Board (CARB) (2020). California's Greenhouse Gas Vehicle Emission Standards under Assembly Bill 1493 of 2002. https://ww2.arb.ca.gov/californias-greenhouse-gas-vehicle-emiss ion-standards-under-assembly-bill-1493-2002-pavley Retrieved from 8 Jan 2021

Capoccia, G. (2015). Critical junctures and institutional change. In J. Mahoney \& K. Thelen (Eds.), Advances in comparative-historical analysis: Strategies for social inquiry (pp. 147-179). Cambridge: Cambridge University Press.

Clark, C. (2018). Renewable energy R\&D funding history: A comparison with funding for nuclear energy, fossil energy, energy efficiency, and electric systems R\&D. Report 22858, Congressional Research Service, Washington, DC.

Congressional Budget Office (CBO) (2020). Budgetary effects of the 2020 coronavirus pandemic. https:// www.cbo.gov/publication/56388. Retrieved from 15 Dec 2020

Congressional Research Service (CRS) (2020). The Renewable Electricity Production Tax Credit: In Brief. Report. https://fas.org/sgp/crs/misc/R43453.pdf Retrieved from 15 Dec 2020

Dunlap, R. E., McCright, A. M., \& Yarosh, J. H. (2016). The political divide on climate change: Partisan polarization widens in the US. Environment: Science and Policy for Sustainable Development, 58(5), $4-23$.

Edmondson, D. L., Kern, F., \& Rogge, K. S. (2019). The co-evolution of policy mixes and socio-technical systems: Towards a conceptual framework of policy mix feedback in sustainability transitions. Research Policy, 48(10), 103832.

Friedman, L. (2019). 'What Is the Green New Deal? A climate proposal, explained', The New York Times, 21 February . https://www.nytimes.com/2019/02/21/climate/green-new-deal-questions-answers.html. Retrieved from 20 Apr 2020

Funk, C., \& Hefferon, M. (2019). U.S. public views on climate and energy (Pew Research Center Survey) https://www.pewresearch.org/science/2019/11/25/u-s-public-views-on-climate-and-energy/ Retrieved from 19 Apr 2020

Galli, A. M., \& Fisher, D. R. (2016). Hybrid arrangements as a form of ecological modernization: The case of the US energy efficiency conservation block grants. Sustainability, 8(88), 1-19.

Geels, F. (2014). Regime resistance against low-carbon transitions: Introducing politics and power into the Multi-Level Perspective. Theory, Culture \& Society, 31(5), 21-40.

Government Publishing Office (GPO). (2005). HR6: Energy Policy Act of 2005. https://www.govinfo.gov/ content/pkg/BILLS-109hr6enr/pdf/BILLS-109hr6enr.pdf. Retrieved from 21 Oct 2020

Green, F., \& Gambhir, A. (2019). Transitional assistance policies for just, equitable and smooth low-carbon transitions: Who, what and how? Climate Policy, 20(8), 902-921. https://doi.org/10.1080/14693 062.2019.1657379.

Harris, P. (2009). Beyond bush: Environmental politics and prospects for US climate policy. Energy Policy, 37(3), 966-971.

Hawlett, M., \& del Rio, P. (2015). The parameters of policy portfolios: verticality and horizontality in design spaces and their consequences for policy mix formulation. Environment and Planning C: Government and Policy, 33, 1233-1245. 
Healy, N., \& Barry, J. (2017). Politicizing energy justice and energy system transitions: Fossil fuel divestment and a 'Just Transition.' Energy Policy, 108, 451-459.

Hickel, J., \& Kallis, G. (2019). Is green growth possible? New Political Economy, 25(4), 469-486.

Hovi, J., Sprinz, D., \& Bang, G. (2012). Why the United States did not become a party to the Kyoto Protocol: German, Norwegian, and U. S. Perspectives. European Journal of International Relations, 18(1), 129-150.

Hultman, N., Frisch, C., Clarke, L., Kennedy K. et al. (2019). Accelerating America's Pledge: Going all-in to build a prosperous, low-carbon economy for the United States. Report, America's Pledge Initiative on Climate Change. Bloomberg Philanthropies, University of Maryland, Rocky Mountain Institute, and World Resources Institute, New York. https://www.americaspledgeonclimate.com/reports/ Retrieved from 14 Dec 2020

Jordan, A., \& Huitema, D. (2014). Innovations in climate policy: the politics of invention, diffusion and evaluation. Environmental Politics, 23, 715-374.

Jordan, A., \& Matt, E. (2014). Designing policies that intentionally stick: Policy feedback in a changing climate. Policy Sciences, 47, 227-247.

Kemp, L. (2015). A climate treaty without the US Congress: Using executive powers to overcome the 'ratification straitjacket'. CCEP Working Paper 1513, Crawford School of Public Policy. http://dx.doi.org/https:// doi.org/10.2139/ssrn.2737637 Retrieved from 30 Jun 2020

Kern, F., Rogge, K. S., \& Howlett, M. (2019). Policy mixes for sustainability transitions New approaches and insights through bridging innovation and policy studies. Research Policy, 48(10), 103832.

Kingdon, J. W. (2003). Agendas, Alternatives, and Public Policies (2nd ed.). Boston: Addison-Wesley Longman Inc.

Kivimaa, P., \& Kern, F. (2016). Creative destruction or mere niche support? Innovation policy mixes for sustainability transitions. Research Policy, 45(1), 205-217.

Laporte, A. (2019). Fossil fuel subsidies: A closer look at tax breaks and societal costs. Report, Environmental and Energy Study Institute. https://www.eesi.org/papers/view/fact-sheet-fossil-fuel-subsidies-a-close r-look-at-tax-breaks-and-societal-costs. Retrieved from 24 Apr 2020.

McCright, A. M., \& Dunlap, R. E. (2011). The politicization of climate change and polarization in the American public's views of global warming, 2001-2010. The Sociological Quarterly, 52(2), 155-194.

Mooney, C. (2019). The Energy 202: Trump's budget seeks cuts to climate research and renewable energy programs. Washington Post, 12 March. https://www.washingtonpost.com/news/powerpost/paloma/the-energ y-202/2019/03/12/the-energy-202-trump-s-budget-seeks-cuts-to-climate-research-and-renewable-energ y-programs/5c869eca1b326b2d177d604d/ Retrieved from 23 Apr 2020

Natter, A. (2019). Trump again seeks deep cuts in renewable energy funding. Bloomberg News, 7 March. https ://www.bloomberg.com/news/articles/2019-03-07/trump-said-to-again-seek-deep-cuts-in-renewable-energ y-funding Retrieved from 23 Apr 2020

National Renewable Energy Laboratory (NREL) (2001). Concentrating Solar Power: Energy from Mirrors. Report DOE/GO-102001-1147, March. https://www.nrel.gov/docs/fy01osti/28751.pdf Retrieved from 8 Jan 2021

Newberger, E. (2020). Rethinking stimulus: How Covid economic recovery can help battle climate change. News article, CNBC, 22 December. https://www.cnbc.com/2020/12/22/covid-economic-recovery-plans -must-battle-climate-change-.html Retrieved from 8 Jan 2021

Ostrom, E. (1990). Governing the commons: The evolution of institutions for collective action. Cambridge: Cambridge University Press.

Pierson, P. (2000). Increasing returns, path dependence, and the study of politics. The American Political Science Review, 94(2), 251-267.

Powell, W. W., \& DiMaggio, P. J. (Eds.). (1991). The New Institutionalism in organizational analysis. Chicago: University of Chicago Press.

Rabe, B. R. (2016). The durability of carbon cap-and-trade policy. Governance: An International Journal of Policy, Administration, and Institution, 29(1), 103-119.

Rabe, B. R. (2004). Statehouse and greenhouse: The emerging politics of American climate change policy. Washington, DC: Brookings.

Rogge, K. S., \& Reichardt, K. (2016). Policy mixes for sustainability transitions: An extended concept and framework for analysis. Research Policy, 45(8), 1620-1635.

Sabin Center for Climate Change Law (2020). Climate deregulation tracker. https://climate.law.columbia.edu/ climate-deregulation-tracker Retrieved from 30 Apr 2020.

Schreurs, M. A., Selin, H., \& VanDeveer, S. (2009). Conflict and cooperation in transatlantic climate politics: Different stories at different levels. In M. A. Schreurs, S. VanDeveer, \& H. Selin (Eds.), Transatlantic environment and energy politics: Comparative and international perspectives (pp. 165-188). Farnham: Ashgate. 
Shipan, C. R., \& Volden, C. (2008). The mechanisms of policy diffusion. American Journal of Political Science, 52(4), 840-857.

Skjærseth, J. B. (2018). Implementing EU climate and energy policies in Poland: Policy feedback and reform. Environmental Politics. https://doi.org/10.1080/09644016.2018.1429046:1-20.

Skocpol, T. (2013). Naming the problem. What it will take to counter extremism and engage Americans in the fight against global warming. Report, Harvard University. https://scholars.org/sites/scholars/files/skocp ol_captrade_report_january_2013_0.pdf

Skocpol, T., \& Pierson, P. (2002). Historical institutionalism in contemporary political science. In I. Katznelson $\&$ H. V. Milner (Eds.), Political science: State of the discipline (pp. 693-721). New York: W.W. Norton.

Skodvin, T., \& Bang, G. (2019). Strategies and counterstrategies for policy durability: The Obama Administration's Affordable Care Act, Clean Power Plan and Methane Waste Prevention Rule two years into the Trump presidency. Presentation, ISA Annual Convention, Toronto, 27-30 March 2019.

Trebilcock, M. J. (2014). Dealing with losers: The political economy of policy transitions. Oxford: Oxford University Press.

Tsebelis, G. (2002). Veto players: How political institutions work. Princeton: Princeton University Press.

United Nations (2020). Sustainable Development Goals Knowledge Platform. https://sustainabledevelopme nt.un.org/?menu=1300. Retrieved from 30 Jun 2020.

US Department of Energy (DOE) (2020). Science and innovation. https://www.energy.gov/science-innovation . Accessed 28 Jun 2020

US Energy Information Administration (EIA) (2018). U.S. Energy-Related Carbon Dioxide Emissions 2017. https://www.eia.gov/environment/emissions/carbon/archive/2017/. Retrieved from 28 Jun 2020.

US Energy Information Administration (EIA) (2020a) The United States consumed a record amount of renewable energy in 2019. Today in Energy. https://www.eia.gov/todayinenergy/detail.php?id=45516 Retrieved from 14 Dec 2020.

US Energy Information Administration (EIA) (2020b). Annual Energy Outlook 2020. https://www.eia.gov/ outlooks/aeo/. Retrieved from 30 Jun 2020.

US Environmental Protection Agency (EPA) (2016). Inventory of U.S. greenhouse gas emissions and sinks: 1990-2014. Report EPA 430-R-16-002. www.epa.gov/climatechange/ghgemissions/usinventoryrepo rt.html. Retrieved from 20 Apr 2020

US Environmental Protection Agency (EPA) (2020). Inventory of U.S. Greenhouse Gas Emissions and Sinks: 1990-2018 - Executive Summary, pp. 3-4. https://www.epa.gov/sites/production/files/2020-04/docum ents/us-ghg-inventory-2020-chapter-executive-summary.pdf Retrieved from 15 Dec 2020

US Senate (2005). Roll Call Vote number 213, 109th Congress - 1st Session. July 29. https://www.senate.gov/ legislative/LIS/roll_call_lists/roll_call_vote_cfm.cfm?congress=109\&session=1\&vote=00213 Retrieved from 8 Nov 2018

Victor, D. G., Geels, F. W., \& Sharpe, S. (2019). Accelerating the low carbon transition: The case for stronger, more targeted and coordinated international action. London: Report for the Department of Business, Energy and Industrial Strategy.

Vogt-Schilb, A., \& Hallegatte, S. (2017). Climate policies and nationally determined contributions: Reconciling the needed ambition with the political economy. WIRES Energy and Environment, 6, e256.

Volden, C. (2006). States as policy laboratories: Emulating success in the children's health insurance program. American Journal of Political Science, 50(2), 294-312.

Wang, Z., \& Krupnick, A. (2013). A Retrospective Review of Shale Gas Development in the United States: What Led to the Boom? Discussion Paper 13-12, Resources for the Future.

Whitley, S. et al. (2018). G7 fossil fuel subsidy scorecard. Policy Brief, Overseas Development Institute, June. https://www.odi.org/sites/odi.org.uk/files/resource-documents/12222.pdf Retrieved from 8 Jan 2021

Wind Energy Technologies Office of the Department of Energy (WETO) (2021). U.S. Department of Energy's Wind Energy Technologies Office-Lasting Impressions. Report DOE/GO-102020-5510, January. https ://www.energy.gov/sites/prod/files/2021/01/f82/WETO-lasting-impressions-2021.pdf Retrieved from 8 Jan 2021

White House (2017) Presidential Executive Order on Promoting Energy Independence and Economic Growth, 28 March. https://www.whitehouse.gov/presidential-actions/presidential-executive-order-promoting-energ y-independence-economic-growth/ Retrieved from 18 Apr 2020

Publisher's Note Springer Nature remains neutral with regard to jurisdictional claims in published maps and institutional affiliations. 